\title{
Observational studies of depression in primary care: what do we know?
}

\author{
Gail Gilchrist* and Jane Gunn
}

\author{
Address: The Department of General Practice, The University of Melbourne, Carlton, Victoria, Australia \\ Email: Gail Gilchrist* - g.gilchrist@unimelb.edu.au; Jane Gunn - j.gunn@unimelb.edu.au \\ * Corresponding author
}

Published: II May 2007

BMC Family Practice 2007, 8:28 doi:10.1/86/147|-2296-8-28

This article is available from: http://www.biomedcentral.com/I47|-2296/8/28

(c) 2007 Gilchrist and Gunn; licensee BioMed Central Ltd.

This is an Open Access article distributed under the terms of the Creative Commons Attribution License (http://creativecommons.org/licenses/by/2.0), which permits unrestricted use, distribution, and reproduction in any medium, provided the original work is properly cited.
Received: 15 September 2006

Accepted: II May 2007

\begin{abstract}
Background: We undertook a systematic review of observational studies of depression in primary care to determine I) the nature and scope of the published studies 2) the methodological quality of the studies; 3 ) the identified recovery and risk factors for persistent depression and 3 ) the treatment and health service use patterns among patients.

Methods: Searches were conducted in MEDLINE, CINAHL and PsycINFO using combinations of topic and keywords, and Medical Subject Headings in MEDLINE, Headings in CINAHL and descriptors in PsycINFO. Searches were limited to adult populations and articles published in English during 1985-2006.

Results: 40 articles from 17 observational cohort studies were identified, most were undertaken in the US or Europe. Studies varied widely in aims and methods making it difficult to meaningfully compare the results. Methodological limitations were common including: selection bias of patients and physicians; small sample sizes (range 35-108 patients at baseline and 20-59 patients at followup); and short follow-up times limiting the extent to which these studies can be used to inform our understanding of recovery and relapse among primary care patients with depression. Risk factors for the persistence of depression identified in this review were: severity and chronicity of the depressive episode, the presence of suicidal thoughts, antidepressant use, poorer self-reported quality of life, lower self-reported social support, experiencing key life events, lower education level and unemployment.
\end{abstract}

Conclusion: Despite the growing interest in depression being managed as a chronic illness, this review identified only 17 observational studies of depression in primary care, most of which have included small sample sizes and been relatively short-term. Future research should be large enough to investigate risk factors for chronicity and relapse, and should be conducted over a longer time frame.

\section{Background}

A recent World Health Organization report states that depression is the leading cause of disability worldwide among people aged five and above [1]. People with depression are mainly managed in primary care/general practice [2], yet current management guidelines are mainly based upon data collected in the secondary and tertiary sectors. Studies of relapse rates, risk factors for 
relapse and efficacy of maintenance therapy have been conducted mainly in tertiary psychiatric settings [3], with a paucity of data from primary care $[4,5]$.

In preparing for an observational study of the health service use and treatment patterns of Australians experiencing depressive symptoms [6] we undertook a systematic review of observational studies of depression in primary care to determine 1) the nature and scope of the published studies 2) the methodological quality of the studies; 3 ) the identified recovery and risk factors for persistent depression and 3) the treatment and health service use patterns among patients.

\section{Methods}

\section{Selection and inclusion criteria}

We selected prospective observational studies where primary care patients were screened for depression and followed over time. Articles were assessed as relevant by both authors. We identified three review articles that described the prevalence and course of depression in primary care $[4,5,7]$, relevant studies from these reviews published during 1985-2006 are included in the current review.

\section{Exclusion criteria}

As the purpose of this review was to examine naturalistic studies receiving routine care, subjects recruited as part of a randomised controlled trial were excluded to reduce bias from selecting patients consenting to participate in intervention or medication trials. It was considered that these patients may not be representative of patients in general practice, as research has found that many primary care patients prefer psychological treatments [8] and therefore may be less likely to enter antidepressant treatment or randomized clinical trials as a result [9]. It has also been shown that subjects in randomised trials have better care and outcomes than 'routine care'. Articles were excluded for the following reasons: patients were origi- nally recruited as part of a randomised controlled trial ( $\mathrm{n}$ = 11) [3,10-19] or an intervention study $(n=1)$ [20]; retrospective analyses of administrative or clinical data were used $(n=6)$ [21-26]; retrospective life charts were used to gain longitudinal data $(\mathrm{n}=1)$ [27]; only primary care patients initiating antidepressant treatment were recruited ( $n=2)$ [28,29]; patients selected were 'psychiatric cases' and results were not presented for depression $(\mathrm{n}=2)$ $[30,31]$; and review articles $(n=1)[5]$.

\section{Search strategy}

An Information Consultant at The University of Melbourne assisted with the development of the search strategy. Searches were conducted separately for each of the following databases: MEDLINE, CINAHL and PsycINFO. Search strategies were devised using combinations of topic and keywords, and Medical Subject Headings (MeSH) in MEDLINE, Headings in CINAHL and descriptors in PsycINFO. Searches were limited to adult populations and articles published in English during 19852006. Figure 1 describes the search statements conducted in each of the three databases searched. Further relevant articles were sourced through cross checking references in articles and from the authors' library.

\section{Results}

The abstracts of 432 articles identified using the search strategy described above were considered (Figure 2). Fiftyone potentially relevant articles were retrieved for comprehensive review. Twenty four articles were excluded as they did not meet criteria for an observational study of depression (see exclusion criteria). Forty articles from 17 observational prospective cohort studies were identified, 27 articles from the original search [32-58] and 13 from secondary references [59-71].

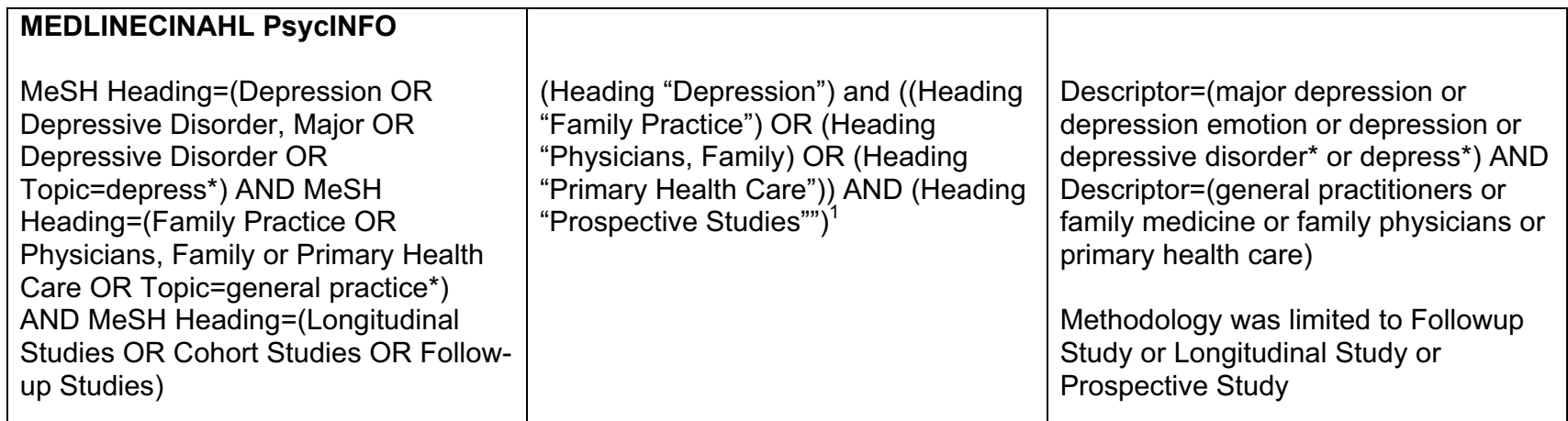

1 In CINAHL Prospective Studies is used for: Cohort Studies; Follow-up Studies; Incidence Studies and Longitudinal Studies

Figure I

Search strategies limited to articles published in English during 1985-2006 and adult populations. 


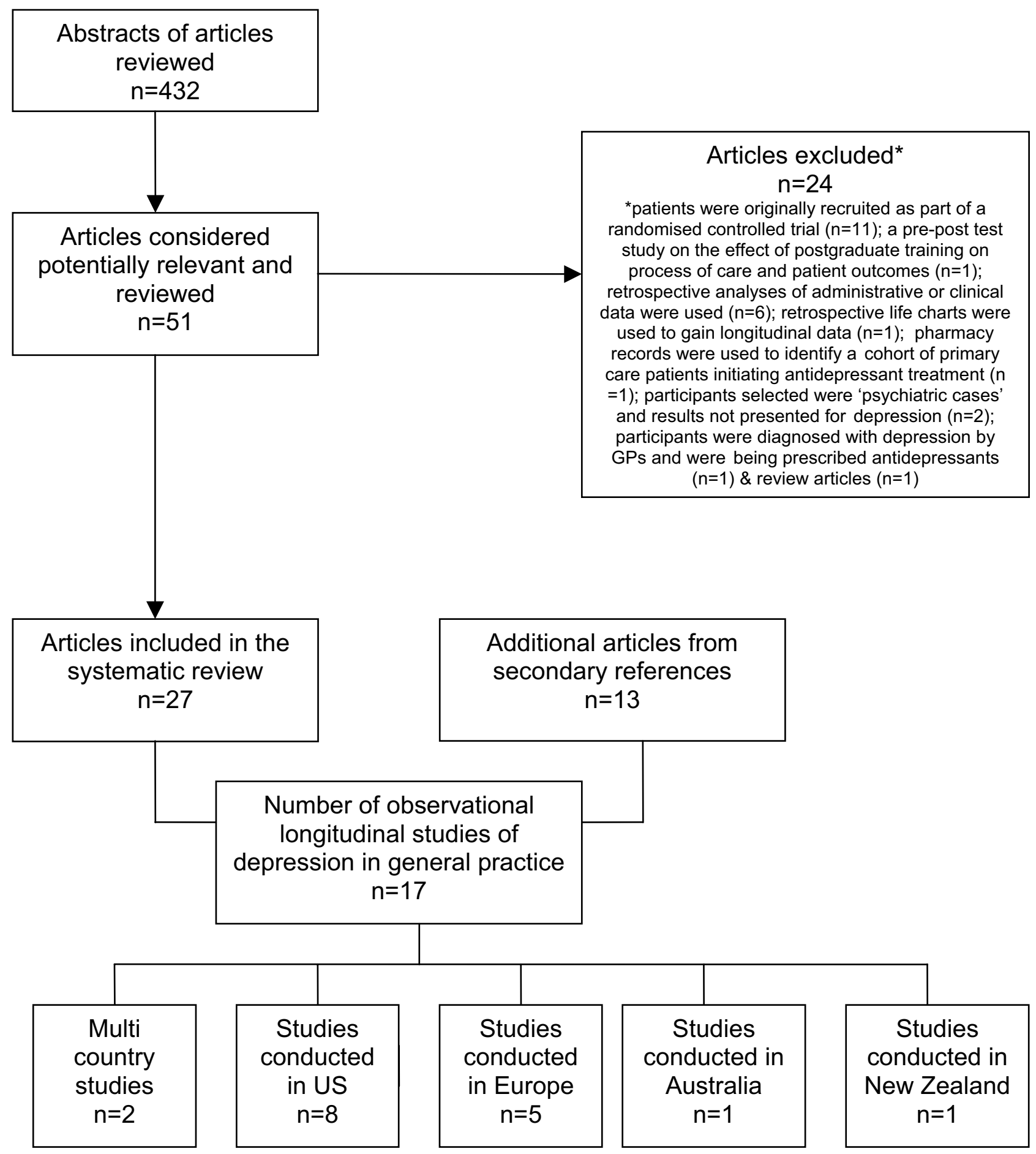

Figure 2

Flowchart of articles included in the review.

\section{Methods used}

Table 1 describes the methods for the 17 longitudinal studies included in the review. The studies varied widely in their original purpose. The studies can be grouped into those that focused on depressive symptoms $(\mathrm{n}=7)$ $[45,51,54,61,63,66,68]$ and those that focused on major depressive disorder satisfying DSM IV criteria $(\mathrm{n}=10)$ $[37,38,43,44,48,49,59,64,67,69]$. Nine of the 17 studies 
aimed to describe the course of depression over time and identify risk factors associated with recovery or improvement in depression $[37,43,44,54,61,63,64,68,69]$. Four studies were interested in examining detection of depression by the practitioner and depression outcome $[38,49,64,66]$. One study examined the seasonality prevalence and incidence of depressive disorder [59], one examined the process and outcomes of rural depression care [67], one examined the outcomes for cases 'missed' at the screening encounter [45], one examined the prevalence of bipolar II disorder with depressive and anxiety subtypes [48], and one examined whether managed care was associated with reduced access to mental health specialists and poorer outcomes among patients with depressive symptoms [51].

Studies varied widely in methods; including the screening and assessment instruments used, eligibility for inclusion in the cohort and the length of follow-up (Table 1). Cohort sizes ranged from 35 [68] to 1336 [51] patients. Follow-up ranged from 20 weeks [68] to 3.5 years [64]. The majority of the studies followed patients for 12 months, with nine studies following patients for less than 12 months (range 20 weeks to 9 months) [37,43,48,49,51,61,66-68] (Table 1).

\section{Setting}

Most studies were undertaken in the US or Europe (Figure 2 ). The review also includes two multi-country studies: the Longitudinal Investigation of Depression Outcomes in primary care (LIDO) [44] and the World Health Organization (WHO) Collaborative Project on Psychological Problems in General Health Care [69]. Several of the study sites (Netherlands [55], Italy [36] and US [57,71]) involved in the multi countries WHO Collaborative Project on Psychological Problems in General Health Care have published results independently. The individual results are presented from these sites alongside the cumulative results from the WHO Collaborative Project on Psychological Problems in General Health Care in Table 2.

\section{Selection procedures}

Consecutive and convenience sampling methods were used in the majority of studies. No study recruited a random sample of patients from primary care. Only six studies detailed how the settings or clinicians were selected: GPs were randomly selected in two studies $[43,63]$; settings were selected in two studies based on research experience and capacity, and on previous collaboration $[44,69]$; GPs were a representative sample from the total population of GPs in the area in one study [64] and in another, GPs were a consenting sub-sample from a larger study on physician referral [51]. Those remaining were conducted on convenience samples selected from health centres [59]; general practices or family practice clinics
$[37,45,48,54,66,68]$, with rural practices [67], from family physicians and a University Psychiatry Outpatient Department [49] or in multi-specialty clinics that had mental health care services, outpatient services, day care and inpatient services [61]. Using statewide telephone screening, one study identified and followed a cohort with a current major depression who made one or more visits to a primary care physician during the six months following baseline [38].

\section{Inclusion criteria}

Six studies included only patients with major depression $[38,43,44,49,59,67]$, three studies included patients with depressive symptoms $[51,66,68]$, two studies included patients with depression or anxiety disorders or symptoms $[37,48]$ and one included 'new' (i.e. a psychiatric diagnosis had not been diagnosed during the 12 months prior to the index visit) and 'old' (i.e. a psychiatric diagnosis had been diagnosed during the 12 months prior to the index visit) patients with depression and anxiety disorders, including borderline disorders and non-specific psychiatric symptoms [35]. Of the remaining five studies, four included patients with depressive symptoms and asymptomatic patients in the follow-up $[45,54,61,63]$ and one included patients with current psychiatric disorder and a random sample of patients without a current psychiatric disorder in the follow-up [69]. Two studies excluded patients who had received recent treatment for depression; one in the previous three months [44] and one where patients had contact with the clinic where the research was being conducted in the six months prior to the study [66]. One study included only non-referred patients presenting with anxiety or depression [48]. One study screened people for depression from random households using state-wide telephone lists and presented follow-up data on those who had visited a general practitioner in the six months following baseline interview [38].

\section{Screening procedures}

Seventeen different instruments were used at baseline to measure depressive symptoms or disorders. The Center for Epidemiologic Studies-Depression Scale (CES-D) [72] and various versions of the General Health Questionnaire (GHQ) [73] were the most commonly used screening instruments (Table 1).

\section{Comorbidity measures}

The majority of studies also measured co-morbid psychiatric symptoms or disorders, mainly anxiety related. Only six examined physical co-morbidities or days out of role $[38,44,48,54,67,69]$. Grembowski et al. [51] reported measuring 21 co-morbid conditions, however these conditions were not reported. 


\begin{tabular}{|c|c|c|c|c|c|c|c|}
\hline Author & Blacker et al. [59] & $\begin{array}{l}\text { Grembowski } \\
\text { et al. [51] }\end{array}$ & $\begin{array}{l}\text { Groningen } \\
\text { Primary } \\
\text { Care Study } \\
{[32-} \\
35,50,64,65]\end{array}$ & $\begin{array}{l}\text { Kessler et al. } \\
{[61]}\end{array}$ & $\begin{array}{l}\text { Kessler et al. } \\
{[45,60]}\end{array}$ & $\begin{array}{l}\text { Limosin et al. } \\
\text { [43] }\end{array}$ & $\begin{array}{l}\text { Longitudinal investigation of } \\
\text { depression outcomes in primary care } \\
\text { (LIDO) }[39,40,44,52,62]\end{array}$ \\
\hline Location & England & US & Netherlands & US & England & France & Israel, Brazil, Spain, Australia, Russia, US \\
\hline $\begin{array}{l}\text { Primary care } \\
\text { setting/s }\end{array}$ & One health centre & $\begin{array}{l}261 \text { primary } \\
\text { physicians in } \\
\text { private } \\
\text { practice from } \\
72 \text { offices }\end{array}$ & $\begin{array}{l}25 \text { General } \\
\text { Practitioners }\end{array}$ & $\begin{array}{l}\text { A multi- } \\
\text { specialty } \\
\text { group practice } \\
\text { with 175 } \\
\text { physicians }\end{array}$ & $\begin{array}{l}\text { One general } \\
\text { practice }\end{array}$ & $\begin{array}{l}560 \text { General } \\
\text { Practitioners }\end{array}$ & $\begin{array}{l}6 \text { research sites Primary care \& outpatient } \\
\text { services, day care services, \& inpatient } \\
\text { hospital services }\end{array}$ \\
\hline $\begin{array}{l}\text { Selection of } \\
\text { primary care } \\
\text { setting }\end{array}$ & Not stated & $\begin{array}{l}\text { Consenting } \\
\text { GPs from } \\
\text { Physician } \\
\text { Referral Study }\end{array}$ & $\begin{array}{l}\text { Representativ } \\
\text { e sample }\end{array}$ & Not stated & Not stated & Randomly selected & $\begin{array}{l}\text { Track record of international collaborative } \\
\text { research }\end{array}$ \\
\hline Recruitment & Consecutive patients & Waiting room & $\begin{array}{l}\text { Consecutive } \\
\text { patients }\end{array}$ & $\begin{array}{l}\text { Patients who } \\
\text { used clinic }\end{array}$ & $\begin{array}{l}\text { Consecutive } \\
\text { patients }\end{array}$ & $\begin{array}{l}\text { Each GP enrolled } \\
\text { first patient to meet } \\
\text { criteria for major } \\
\text { depressive episode }\end{array}$ & Patients attending primary care facilities \\
\hline $\begin{array}{l}\text { Screen for } \\
\text { depression/ } \\
\text { mental } \\
\text { health }\end{array}$ & $\begin{array}{l}\text { General Health } \\
\text { Questionnaire } \\
\text { (GHQ)-30, Schedule } \\
\text { for Affective } \\
\text { Disorders and } \\
\text { Schizophrenia } \\
\text { (SADS) }\end{array}$ & $\begin{array}{l}\text { Symptom } \\
\text { Checklist } \\
\text { (SCL) }-20\end{array}$ & $\begin{array}{l}\text { GHQ-30 \& } \\
\text { rated by GP } \\
\text { for current } \\
\text { mental health } \\
\text { problem }\end{array}$ & GHQ-30 & GHQ-12 & $\begin{array}{l}\text { Structured Clinical } \\
\text { Interview for DSM } \\
\text { (SCID) }\end{array}$ & $\begin{array}{l}\text { Center for Epidemiologic Studies- } \\
\text { Depression Scale (CES-D) }\end{array}$ \\
\hline $\begin{array}{l}\text { Exclusion } \\
\text { criteria }\end{array}$ & Not stated & $\begin{array}{l}<18 \text { years, non } \\
\text { English } \\
\text { speaking }\end{array}$ & Not stated & Not stated & Not stated & $<18$ years & $\begin{array}{l}\text { Recent treatment for depression; psychoses; } \\
\text { dementia; any other condition would } \\
\text { interfere with the study objectives }\end{array}$ \\
\hline $\begin{array}{l}\text { Criteria for } \\
\text { inclusion in } \\
\text { cohort }\end{array}$ & $\begin{array}{l}\text { Depressive } \\
\text { disorders }\end{array}$ & $\begin{array}{l}\text { Depressive } \\
\text { symptoms }\end{array}$ & $\begin{array}{l}\text { Three or } \\
\text { more } \\
\text { psychiatric } \\
\text { symptoms on } \\
\text { PSE }\end{array}$ & $\begin{array}{l}192 \text { patients } \\
\text { with GHQ-30 } \\
\text { scores }=4 \& \\
55 \text { with lower } \\
\text { scores }\end{array}$ & $\begin{array}{l}\text { Completion of } \\
\text { GHQ }\end{array}$ & $\begin{array}{l}\text { Major Depressive } \\
\text { Episode \& scored } \\
\text { Montgomery- } \\
\text { Asberg Depression } \\
\text { Rating Scale } \\
\text { (MADRS) } \geq 20\end{array}$ & Major depression \\
\hline $\begin{array}{l}\text { Measurement } \\
\text { of depression } \\
\text { at baseline }\end{array}$ & SADS & - & $\begin{array}{l}\text { Present State } \\
\text { Exam (PSE) }\end{array}$ & $\begin{array}{l}\text { SADS-Lifetime } \\
\text { Version }\end{array}$ & $\begin{array}{l}\text { Clinical } \\
\text { Interview } \\
\text { Schedule (CIS) }\end{array}$ & $\begin{array}{l}\text { SCID, Clinical } \\
\text { Global Impression } \\
\text { (CGI), MADRS }\end{array}$ & $\begin{array}{l}\text { Composite International Diagnostic } \\
\text { Interview (CIDI), CES-D }\end{array}$ \\
\hline $\begin{array}{l}\text { Cohort }(\% \\
\text { female) }\end{array}$ & $\begin{array}{l}196(\% \text { female not } \\
\text { stated) }\end{array}$ & $\begin{array}{l}\text { I } 336 \text { [Data } \\
\text { presented on } \\
942(74 \% \\
\text { female) } \\
\text { insured } \\
\text { patients with } \\
\text { complete } \\
\text { follow ups] }\end{array}$ & $\begin{array}{l}201 \text { ( } 64 \%-71 \% \\
\text { across onset } \\
\text { groups) } \\
\text { [Includes } 20 \\
\text { participants } \\
\text { with } \\
\text { depression } \\
\text { and } 13 \text { with } \\
\text { borderline } \\
\text { depression] }\end{array}$ & $\begin{array}{l}247 \text { at first } \\
\text { interview } \\
\text { [Paper reports } \\
\text { only on } 166 \\
\text { followed up } \\
\text { ( } 54 \% \text { female)] }\end{array}$ & $\begin{array}{l}305(74 \%) \\
{[305(74 \%)} \\
\text { screened with } \\
\text { GHQ in cross } \\
\text { sectional study } \\
\text { in } 1997 \\
\text { (Kessler et al., } \\
1999)[52 \% \\
\text { (157/305) } \\
\text { GHQ +ve at } \\
\text { screening, not } \\
\text { clear from } \\
2002 \text { paper } \\
\text { how many of } \\
\text { the } 157 \text { were } \\
\text { found again in } \\
2002 \text { paper] } \\
\text { [60]] }\end{array}$ & $492(72 \%)$ & 1117 (ranged across sites: $54-71 \%$ ) \\
\hline
\end{tabular}

Mental Health \& General Practice Manning et

Mental Health \& General Prati
Investigation (MaGPie) [63]

Manning
al. [48]

New Zealand

70 General Practitioners

US

One private

ambulatory

family practice

Not stated

Randomly selected

All adult attenders

Consecutive

non-referred
patients

patients

presen
with

impairment

due to

depression or

GHQ-12

anxiety

5 question

screening
instrument

$<18$ years, not able to read English \& consulting with GP other than index GP

Not stated

$\mathrm{GHQ} \geq 5$, + those scoring GHQ 2-4 had Non referred a random $50 \%$ of those not selected by with GHQ but whom the GP had identified as impairment having psychological problems were also due to anxiety selected or depression

CIDI, Somatic and Psychological Health SCID

$908(66 \%)$

$108(80 \%)$

$[108$

patients were

prospectively

proser

paper does
not state if

this is the total

number in

cohort or

those retained 
Table I: Methods (Continued)

\begin{tabular}{|c|c|c|c|c|c|c|c|c|c|}
\hline $\begin{array}{l}\text { Duration of } \\
\text { follow-up }\end{array}$ & 12 months & 6 months & 3.5 years & 6 months & 3 years & 6 months & 12 months & 12 months & $\begin{array}{l}8 \text { months } \\
\text { median follow } \\
\text { up (Range I-- } \\
72 \text { months) }\end{array}$ \\
\hline $\begin{array}{l}\text { Other } \\
\text { comorbidity } \\
\text { measured }\end{array}$ & No & Yes & Yes & Yes & Yes & Yes & Yes & Yes & Yes \\
\hline $\begin{array}{l}\text { Care } \\
\text { received } \\
\text { examined }\end{array}$ & No & Yes & Yes & Yes & Yes & Yes & Yes & Yes & Yes \\
\hline $\begin{array}{l}\text { Definition of } \\
\text { depression } \\
\text { outcome }\end{array}$ & $\begin{array}{l}\text { Loss of key } \\
\text { symptoms \& } \\
\text { syndromal status + } \\
\text { return to normal } \\
\text { functioning for a } \\
\text { minimum of } 2 \\
\text { months }\end{array}$ & Not stated & $\begin{array}{l}\text { Nolonger met } \\
\text { criteria for } \\
\text { baseline } \\
\text { diagnosis }\end{array}$ & $\begin{array}{l}\text { Remitted } \\
\text { cases were } \\
\text { those with } \\
\text { positive } \\
\text { SADS-L } \\
\text { diagnosis at } \\
\text { baseline but } \\
\text { not at follow } \\
\text { up }\end{array}$ & $\begin{array}{l}\text { No longer } \\
\text { case on GHQ- } \\
12\end{array}$ & $\begin{array}{l}\text { Symptomatic } \\
\text { exacerbation } \\
\text { (MADRS score > } \\
\text { 20) among patients } \\
\text { who had responded } \\
\text { to treatment but } \\
\text { had not yet been } \\
\text { well for a sufficient } \\
\text { amount of time } \\
\text { (under } 6 \text { months) }\end{array}$ & Complete remission from major depression & Results not yet available on outcome & Not stated \\
\hline Author & $\begin{array}{l}\text { Michigan } \\
\text { Depression } \\
\text { Project [47, 49] }\end{array}$ & $\begin{array}{l}\text { Parker et al. } \\
{[68]}\end{array}$ & $\begin{array}{l}\text { Ronalds et } \\
\text { al. [37] }\end{array}$ & $\begin{array}{l}\text { Rost et al. } \\
{[67]}\end{array}$ & $\begin{array}{l}\text { Rost et al. } \\
{[38]}\end{array}$ & $\begin{array}{l}\text { Schulberg et. } \\
{[66]}\end{array}$ & Wagner et al. $[42,54]$ & \multicolumn{2}{|c|}{$\begin{array}{l}\text { WHO Collaborative Project on Psychological } \\
\text { Problems in General Health Care } \\
{[41,46,53,56,58,69,70]}\end{array}$} \\
\hline Location & US & Australia & England & US & US & US & US & \multicolumn{2}{|c|}{$\begin{array}{l}15 \text { centres in } 14 \text { countries [Countries included in the study } \\
\text { are: India, Turkey, Greece, Germany, The Netherlands } \\
\text { [55], Nigeria, UK, Japan, France, Brazil, Chile, US [57,70], } \\
\text { China \& Italy [36] }\end{array}$} \\
\hline $\begin{array}{l}\text { Primary care } \\
\text { setting/s }\end{array}$ & $\begin{array}{l}\text { Family physicians \& } \\
\text { University of } \\
\text { Michigan, } \\
\text { Department of } \\
\text { Psychiatry } \\
\text { Outpatient } \\
\text { Depression Program }\end{array}$ & $\begin{array}{l}12 \text { General } \\
\text { Practices }\end{array}$ & $\begin{array}{l}\text { One General } \\
\text { Practice with } \\
\text { an attached } \\
\text { psychiatric } \\
\text { social worker, } \\
\text { a visiting } \\
\text { pyychiatrist \& } \\
\text { a clinical } \\
\text { psychologist at } \\
\text { the health } \\
\text { centre }\end{array}$ & $\begin{array}{l}21 \text { primary } \\
\text { care practices }\end{array}$ & $\begin{array}{l}\text { Using } \\
\text { statewide } \\
\text { telephone } \\
\text { screening, } \\
\text { identified and } \\
\text { followed a } \\
\text { cohort with a } \\
\text { current major } \\
\text { depression } \\
\text { who made one } \\
\text { or more visits } \\
\text { to a primary } \\
\text { care physician } \\
\text { during the six } \\
\text { months } \\
\text { following } \\
\text { baseline }\end{array}$ & $\begin{array}{l}\text { One general medical } \\
\text { clinic \& two family } \\
\text { practice clinics }\end{array}$ & One university-based family practice clinic & \multicolumn{2}{|c|}{$\begin{array}{l}\text { Health centre, primary health care unit, outpatient clinic, } \\
\text { GP offices \& private clinics, family practice, neighbourhood } \\
\text { hospital \& district hospital, primary care clinic }\end{array}$} \\
\hline $\begin{array}{l}\text { Selection of } \\
\text { primary care } \\
\text { setting }\end{array}$ & Not stated & Not stated & Not stated & Not stated & Not stated & Not stated & Not stated & \multicolumn{2}{|c|}{$\begin{array}{l}\text { Previous successful WHO collaboration, research } \\
\text { experience in primary care, access to patient population }\end{array}$} \\
\hline Recruitment & Waiting room & $\begin{array}{l}\text { Consecutive } \\
\text { patients }\end{array}$ & $\begin{array}{l}\text { All surgery } \\
\text { attenders }\end{array}$ & $\begin{array}{l}\text { Consecutive } \\
\text { patients }\end{array}$ & $\begin{array}{l}\text { Statewide } \\
\text { telephone } \\
\text { screening, } \\
\text { those who } \\
\text { were } \\
\text { depressed } \\
\text { invited for } \\
\text { telephone } \\
\text { interview }\end{array}$ & $\begin{array}{l}\text { Patients completed } \\
\text { a depression } \\
\text { screening } \\
\text { instrument } \\
\text { presented to them } \\
\text { by receptionist }\end{array}$ & $\begin{array}{l}\text { Patients introduced to RA by family physician } \\
\text { at end of clinical visit }\end{array}$ & \multicolumn{2}{|l|}{ Consecutive patients } \\
\hline $\begin{array}{l}\text { Screen for } \\
\text { depression }\end{array}$ & CES-D & $\begin{array}{l}\text { Beck } \\
\text { Depression }\end{array}$ & GHQ-28 & $\begin{array}{l}\text { 3-item screen } \\
\text { for major }\end{array}$ & $\begin{array}{l}\text { Burnam } \\
\text { screener }\end{array}$ & CES-D & CES-D & \multicolumn{2}{|l|}{ GHQ-12 } \\
\hline
\end{tabular}


$\stackrel{\infty}{N}$ Table I: Methods (Continued)

\begin{tabular}{ll}
\hline $\begin{array}{l}\text { Exclusion } \\
\text { criteria }\end{array}$ & Not stated \\
& \\
$\begin{array}{ll}\text { Criteria for } \\
\text { inclusion in } \\
\text { cohort }\end{array}$ & Major depression \\
& \\
$\begin{array}{ll}\text { Measurement } \\
\text { of depression } \\
\text { at baseline }\end{array}$ & $\begin{array}{l}\text { SCID, CES-D, } \\
\text { Hamilton Rating } \\
\text { Scale for Depression } \\
\text { (HAM-D) }\end{array}$ \\
& \\
&
\end{tabular}

$\begin{array}{lll}\begin{array}{l}\text { Inadequate } \\ \text { knowledge of }\end{array} & \begin{array}{l}\text { Not meeting } \\ \text { DSM-III-R }\end{array} & \begin{array}{l}\text { No access to a } \\ \text { telephone }\end{array}\end{array}$

knowledge

severely

criteria for

Bereaved,

manic, acutely

Contact with clinics

Being seen by the Duke Student Health

$<18$ years, $>65$ years, too ill, no fixed address, did not $\stackrel{\infty}{\frac{1}{0}}$

denied

months prior

Service, employees of the Department of

come for a medical consultation, communication problem,

index assessment

physically

symptoms

CES-D $\geq 16$

CES-D $\geq 16+$ random sample of CES-D $<16$

Current psychiatric disorder at baseline diagnostic

Met DSM-III-R Major Major

criteria for depression depression

CES $\geq 16$

assessment \& $20 \%$ random sample

anxiety, panic

disorder

past \& current Psychiatric

Psychiatric

(Diagnostic

DIS

DIS, CES-D

CIDI-Primary Health Care, GHQ-28

PSE, Zung Schedule Module Schedule) DIS

Depression (PAS), (DOS),

Scale (ZDS) \& Hamilton Inventory to

Depression Diagnose

Depression

(HDRS),

Anxiety Scale

Cohort
female)

81 from primary
care (\% not stated)

35 (86\%)

182 with

$47(81 \%)$

anxiety or

panic disorder

Reports on

$148(67 \%$

followed up]

Duration of 9 months

20 weeks

6 months

5 months

12 months

6 months

12 months

213 (range $61-8$
categories)

Yes

Yes

Yes

Yes

comorbidity

measured

Care

Yes

Yes Yes

Yes

Yes

Yes

Yes

Yes

Definition of Improvement in improvement Change in Remission

HAM-D score

$\begin{array}{lll}\text { improvement } & \text { Change in } & \text { Remission } \\ \text { in Zung scores } & \text { HDRS scores } & \text { from maior }\end{array}$

$\begin{array}{lll}\text { changes in } & \text { from major } \\ \text { depression } & \text { of } 9 \text { criteria for }\end{array}$

Remission:
of $9 \mathrm{DIS}$

CAS scores \&

reduction in

index of deition level

major

depression

2 weeks.

Resolution of major Improvement i.e. moved to a less severe

depressive disorder diagnostic category

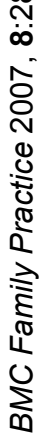


Table 2: Results

\begin{tabular}{|c|c|c|c|c|c|c|c|}
\hline Author & $\begin{array}{l}\text { Blacker et al. } \\
\text { [59] }\end{array}$ & Grembowski et al. [5I] & $\begin{array}{l}\text { Groningen Primary Care } \\
\text { Study }[32-35,50,64,65]\end{array}$ & Kessler et al. [6I] & $\begin{array}{l}\text { Kessler et al. } \\
{[45,60]}\end{array}$ & Limosin et al. [43] & $\begin{array}{l}\text { Longitudinal investigation of } \\
\text { depression outcomes in } \\
\text { primary care (LIDO) [39,40, } \\
44,52,62]\end{array}$ \\
\hline
\end{tabular}

\begin{tabular}{|c|c|c|}
\hline Retention & $\begin{array}{l}72 \%(142 / 196) \\
\text { [Retention } \\
\text { calculated from } \\
\text { data presented in } \\
\text { paper as not stated } \\
\text { in results] }\end{array}$ & $71 \%(942 / 1336)$ \\
\hline $\begin{array}{l}\text { Recovery from/ } \\
\text { improvement in } \\
\text { depression }\end{array}$ & $\%$ not stated & $\begin{array}{l}\text { SCL-20 significantly reduced at } \\
6 \text { months }(I .72 \text { to } 0.91, p< \\
0.001) \text {. Restricted activity days } \\
\text { due to emotional health } \\
\text { significantly reduced at } 6 \\
\text { months }(6.00 \text { to } 2.67 \text { days, } p< \\
0.001 \text { ) }\end{array}$ \\
\hline Predictors of & No data presented & No data presented \\
\hline
\end{tabular}

$77 \%(154 / 201)$

$67 \%(166 / 247)$

$59 \%(179 / 305)$

[Paper reports on
88 of original 157

$86 \%(424 / 492)$

$87 \%(968 / /|1| 7)$ [Data presented for

[60]]

$32 \%$ at 12 months \& $47 \%$ at 3.5 years

At 6 months, major depression was present in $33 \%$ of both the

No data presented

Positive life change increased the probability of remission in wom fourfold ( $H R=4.4)$, but not in men. Predictors of faster time to remission were low severity of high self-esteem $(H R=1.4)$, and coping style aimed at reducing tension (HR $=1.4)$ [32].

Treatment

$61 \%$ received no treatment during follow up \& $29 \%$ treatments of a type intensity \&
degree that would be considered "therapeutic"

At follow up, $23 \%$ (219/942) of Recognition of psychiatric patients had been referred \& $38 \%$ (356/942) had visited a visited a psy specialist. $54 \%$ visited a psychologist, $12 \%$ a Patients who saw a mental health specialist had more visits for depression to a primary physician than those who did not see a mental health

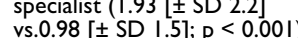

Author

Mental Health \& Manning et al. [48] General Investigation (MaGPie) [63]

Retention $83 \%$ ( $753 / 908)$, $77 \%$ final magpie
interview (696)

108

N

음

Recovery from/ No data presented No data presented improvement in 列order by a GP among new ikelihood of referral to a mental health specialist (OR 3.0), medications (OR 4.5), having a counseling session (OR 12.2) and having any mental health
treatment (OR 6.7) [64]

\section{Michigan Depression Project
$[47,49]$}

No data presented between the first \& second interview had the highest tota ambulatory use, primary \& specialty care of all types ( 9.23$)$ cases \& 8.35 visits for continuing cases], while patients with continuing cases had the highest mean number of primary care visits (4.54) [3.19 visits for no diagnosis group, 3.35 visits for new cases]

Parker et al. [68]

$73 \%(59 / 81)$ of primary care patients [Data presented for 4.5
month follow up]

$57 \%(20 / 35)$

Detected primary care patients mprovement in HAM-D scores 4.5 months. Both undetected primary care \& detected psychiatric patients showed significant improvements over 4.5 patients in all 3 groups had improved \& no longer met criteria for MDD [47]] na 2 continuing case groups $\&$ $50 \%(16 / 32)$ of those not detected by a GP at baseline follow up

No data presented depressive disorder was
associated with a higher
risk of relapse (OR 1.6,
$95 \% \mathrm{Cl} 1.08-3.43)$

Patients developing disorders $\quad 68 \%(38 / 56)$ with .

$65 \%$ (308/476) recovered 35\% (340/968) complete remission $\begin{array}{ll}\text { without relapse, } 25 \% \text { ( }(117 / & \text { (range } 25 \%-48 \% \text { across sites) [Data } \\ \text { 476) developed a chronic } & \text { presented for } 9 \text { month follow up] }\end{array}$ (11\% (51/476) relapsed after recovery

Education, key life events, \& the Quality of Life Depression Scale score at baseline predicted complete remission after adjusting for centres, socio-demographic

comorbidity \& general quality of life

diagnosis, were treated with

antidepressants \& $21 \%(12 / 56)$ were psychiatric services

All received an antidepressant treatment during the 6-month period. The total duration of treatment was $<3$ months between 30-60 days for $21 \%, \&$ between $60-90$ days for $9 \%$. Duration of treatment was between $3-$
6 months for $14 \%$ of 6 months for $14 \%$ of patients \& $\geq 6$ months for

$0 \%(0 \%)$ in St Petersburg to 38\% $(33 \%)$ in Seattle received

antidepressants (an effective dose) to $3 \%$ in St Pep. 29\% in Melbourne to $3 \%$ in St Petersburg received any likelihood of receiving potentially effective antidepressant or menta health treatment at 3 months or 9 months did not differ across sites between the patients who were in complete remission \& those who

Rost et al. [67]

Rost et al. [38]

$81 \%(148 / 182), 74 \quad 81 \%(38 / 47)$

with major

depressive disorder

generalized anxiety
or panic disorders

42.6 at baseline to $40 . \mathrm{I}$ at follow Median HDRS score (12/38) 9-15) at baseline to 5 five (interquartile

range $1-10)$
follow up
94\% (152/162) [Paper reports on 98 patients visiting a primary care following baseline]

Remission: $36.9 \%$ of undetected patients and $29.2 \%$ of detected patients at 12 month follow up.
Improvement: $10.2 \%$ of undetected patients and $9.8 \%$ of detected patients at 12 month follow up 
Table 2: Results (Continued)

No data presented

\section{Predictors}

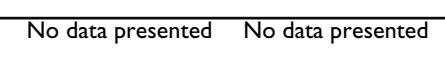

Baseline predictors of a better outcome (improvement) were having a history of episodic or severe depression; lowor class; break up of an intimate relationship as a precipitant; a neutralizing life event \& family support

Treatment

$$
\begin{aligned}
& \text { In the year } \\
& \text { preceding the } \\
& \text { index consultation, } \\
& 1 / 3 \text { of male } \& 42 \% \\
& \text { of female patients }
\end{aligned}
$$
had five or more
GP consultations

Not purpose of paper

In the past 6 months: $75 \%$ of primary care patients had been prescribed medication, $88 \%$ \& $29 \%$ respectively had been counseled by physician, $56 \%$ $12 \%$ had been referred for counseling \& $36 \%$ \& $3 \%$ individual or group therapy

At follow up, 2 were still were continuing to see their GP for depression
Author

\section{Schulberg et.} [66]

Retention $\quad 93 \%(274 / 294) \quad 86 \%(184 / / 213)$

Recovery from/ $\quad 71 \%(12 / 17)$ improvement in depression
$37 \%(19 / 5 I)$ of patients with major depression at baseline were asymptomatic at 12
months \& $56 \%(37 / 66)$ of patients with minor depression at baseline were asymptomatic anxiolytic medication, while

\section{A reduction in soc} difficulties, high baseline HDRS score, higher and current employment wer associated with greater reduction
HDRS scores HDRS scores

(adjusted

In 93 patients the was recognised \&

managed as follows: 30 patients by discussion/ counseling without GP with

psychotropic drugs referred to the specialist services. The greatest depression was in the patients managed witho psychotropic drugs $\&$ referred to mental health

services.

WHO Collaborative Project on Psychological Problems in General Health

WHO Collaborative Project Pychological Problems in Collaborative [36]

\section{Collaborative
Project on}

Psychological
Problems in

General Health
Care (US) $[57,71]$

$62 \%(729 / 1174)$ of patients with depressive episode

$67 \%(482 / 725)$ Of the 29 participants with
baseline threshold major
depression, $21 \%(n=7)$ were
well at 12 months \& $14 \%(n=4)$
were subthreshold
At the 12-month assessment, 15/50

(30\%) patients

continued to satisfy depressive disorder, criteria for minor (62\%) did not satisfy depressive disorder
No data presented pharmacologic treatment

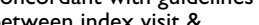

follow up were more likely

to be in remission at follow

up than subjects who did not $\left(X^{2}=3.8, p<0.05\right)$

$63 \%(24 / 38)$ filled prescriptions for one or more antidepressant

medications between index
visit \& follow up. $29 \%$ ( 11 . 38) received pharmacologic treatment concordant wi patients received 3 or more counseling sessions from a mental health professional.

$52 \%$ of detected patients had a prescription for antidepressant medication during the year following baseline, $27 \%$ completed course in (cordance with guidelines. $7 \%$ of fom their primary care physician to Ith specialist in a prescription for ntidepressant medication.
WHO Collaborative Project on in Generalcal Problems (Netherlands) [55]

At 12 months, 32\% (2I/66) diagnosis recovered $(50 \%$ (21/79) patients whose ICD-I0 diagnosis was not recognized by a GP recovered (47\% (37/79) improved) 


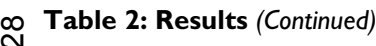

\begin{tabular}{|c|c|c|c|c|c|c|}
\hline $\begin{array}{l}\text { Predictors of } \\
\text { outcome }\end{array}$ & $\begin{array}{l}\text { Psychiatric status } \\
\text { at initial } \\
\text { assessment \& the } \\
\text { number of } \\
\text { assigned medical } \\
\text { diagnoses rather } \\
\text { than the physicians } \\
\text { recognition \& } \\
\text { treatment of } \\
\text { depression } \\
\text { strongly predict } \\
\text { continued affective } \\
\text { disorder }\end{array}$ & $\begin{array}{l}\text { Risk for persistent depression } \\
\text { at } 12 \text { months for those with } \\
\text { major depression at baseline } \\
\text { was } 44 \% \text { greater in those with } \\
\text { co-existing anxiety disorder } \\
\text { (RR I.44, } 95 \% \text { Cl } 1.02-2.04 \\
{[42]}\end{array}$ & 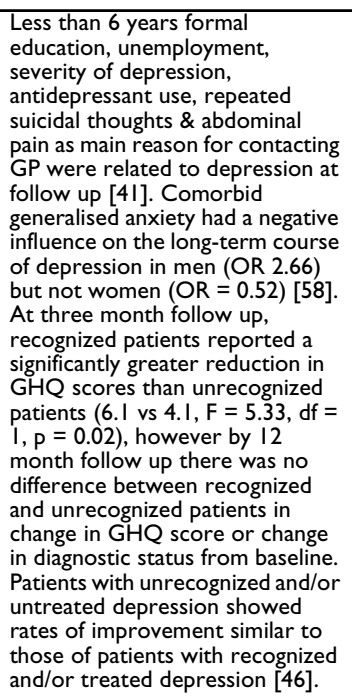 & $\begin{array}{l}\text { Recognition of mental disorder } \\
\text { by the physician at baseline was } \\
\text { not associated with an } \\
\text { improvement of psychopathology } \\
\text { after } 12 \text { months, but was } \\
\text { associated with an improvement } \\
\text { in occupational disability \& self- } \\
\text { reported disability among } \\
\text { threshold cases }\end{array}$ & $\begin{array}{l}\text { The likelihood of } \\
\text { complete remission } \\
\text { (no depressive } \\
\text { diagnosis at I2- } \\
\text { month follow-up) } \\
\text { was } 60 \% \text { ( } 21 \text { of } 35) \\
\text { for the recognized } \\
\text { group \& } 68 \% \text { (10 of } \\
\text { 15) }\end{array}$ & $\begin{array}{l}\text { Patients whose } \\
\text { psychological disorder was } \\
\text { recognized had no better } \\
\text { outcomes than those } \\
\text { whose disorder was not } \\
\text { recognized }\end{array}$ \\
\hline Treatment & $\begin{array}{l}\text { Among the } 9 \text { of I3 } \\
\text { patients } \\
\text { (depression not } \\
\text { recognized by GP) } \\
\text { whose depression } \\
\text { remitted, } 5 \\
\text { received no } \\
\text { antidepressants, } \\
\text { one received only } \\
25 \mathrm{mg} \text { of } \\
\text { Imipramine, } 2 \\
\text { received an anti- } \\
\text { anxiety drug \& one } \\
\text { received sleeping } \\
\text { medications. } 3 \\
\text { received } \\
\text { Psychiatric } \\
\text { treatment at a } \\
\text { psychiatric facility } \\
\text { during the study } \\
\text { period }\end{array}$ & $\begin{array}{l}\text { Odds for a visit to a mental } \\
\text { health specialist or in the } \\
\text { general medical sector for } \\
\text { mental health purposes were } \\
\text { significantly higher for } \\
\text { respondents with a diagnosis of } \\
\text { major depression relative to } \\
\text { respondents with minor } \\
\text { depression \& significantly lower } \\
\text { again for asymptomatic } \\
\text { respondents, again relative to } \\
\text { the minor depression group. In } \\
\text { multivariate modeling, female } \\
\text { gender, white race, \& higher } \\
\text { education was associated with } \\
\text { higher odds of a mental health } \\
\text { visit [54] }\end{array}$ & $\begin{array}{l}\text { Those depressed at follow-up } \\
\text { were twice as likely to be taking } \\
\text { antidepressants (20\%) as non- } \\
\text { depressed at follow- up ( } 11 \%)\end{array}$ & Not presented & $\begin{array}{l}\text { Of patients with } \\
\text { major depressive } \\
\text { disorder ( } \mathrm{n}=64) \text {, } \\
\text { pharmacy records } \\
\text { showed that a total } \\
\text { of } 36(56 \%) \text { received } \\
\text { antidepressant } \\
\text { medications at some } \\
\text { time during the } 3 \\
\text { months following } \\
\text { screening. Of them, } \\
28(78 \%) \text { received } \\
\text { dosages within the } \\
\text { recommended } \\
\text { ranges \& } 27 \text { (75\%) } \\
\text { continued to refill } \\
\text { antidepressant } \\
\text { prescriptions for at } \\
\text { least } 90 \text { days. Both } \\
\text { dosage \& duration } \\
\text { of treatment met } \\
\text { these standards in } \\
22 \text { (61\%) of } 36 \\
\text { cases. Among those } \\
\text { with major } \\
\text { depression, } 39 \% \\
\text { (23/59) of visited at } \\
\text { least one specialty } \\
\text { mental health since } \\
\text { screening. } 66 \% \text { (39/ } \\
59) \text { received some } \\
\text { treatment during } \\
\text { the } 3 \text { month follow } \\
\text { up. Likelihood of } \\
\text { receiving treatment } \\
\text { was strongly related } \\
\text { to severity of illness. }\end{array}$ & Not presented \\
\hline
\end{tabular}




\section{Treatment and health service use}

Only one study did not report on the care received by patients [59]. Two of the sixteen studies that report collecting data on health service use did not report the findings [38,61]. While Kessler et al. [61] reviewed medical records, their purpose was to determine point recognition and validate mental disorders given in the context of an associated physical disorder, not to examine care received. Rost et al. [38] examined medical, pharmaceutical and insurance records to determine the detected and undetected depression during follow-up. Five studies examined medication use $[44,48,63,68,69]$ and two presented data on the use of antidepressant medication [51,67]. Seven studies examined health care/service utilization $[44,49,54,63,66,67,69]$ and one described use of and referral to mental health specialists [51]. Parker et al. [68] examined GP and psychiatric care, and four studies examined GP treatment $[37,45,63,64]$. The MaGPie Research Group [63] also examined barriers to care and patients' attitudes to their GP. Seven studies asked patients to self report on the care they received between baseline and follow-up $[37,44,51,54,63,66,69]$, four studies asked the primary care physician to report on care $[43,49,63,64]$ and eight reviewed medical records, chart evidence, insurance records and/or pharmaceutical records $[37,38,45,48,51,63,66,67]$ [results not mutually exclusive]. Parker et al. [68] collected data on medication, GP and psychiatric care during follow-up, however they did not report whether the data were patient self-report, physician report or a review of records.

\section{Methodological quality of the studies included in the review}

Many of the studies have methodological limitations, including small sample sizes (range 35-108 patients at baseline and 20-59 patients at follow-up) $[48,49,67,68]$ and small numbers in the cohort with depression $[35,66]$. Furthermore, Schulberg et al. [66] was the only study to consider characteristics of the sample screened with the primary care population to determine whether the study patients were representative. No study randomly selected general practices and then approached a random selection of their patient list to avoid the frequency of attendance bias present in studies recruiting consecutive patients. Previous research has highlighted that a high proportion of eligible patients are missed when recruiting patients from general practice waiting rooms, thus limiting the generalisability of the findings [74]. Moreover, only three studies included a random or representative sample of primary care physicians $[43,63,64]$, and seven studies recruited patients from just one centre or general practice $[37,45,48,54,59,61,66]$. These methodological limitations must be acknowledged when considering whether findings from the studies included in this review can be generalised to primary care populations.

\section{Representativeness of samples to the primary care population}

Only one study was able to compare characteristics of the sample screened with the primary care population [66]. Schulberg et al. [66] compared their cohort of patients with depressive symptoms with the total clinic population and noted the cohort was younger and had more females than would be expected from the medical facilities where the research took place. Rost et al. [38] compared patients who agreed to take part in the baseline interview with those patients who were eligible but refused, and reported no differences in socio-demographic data and clinical characteristics including the severity of depression, except that the cohort were younger and more likely to live in metropolitan areas.

Between $62 \%-91 \%$ of patients were retained in the studies at 12 months, and 67\%-93\% at six months (Table 1). However, as some cohorts included asymptomatic patients $[45,54,61,63,69]$, the power of some studies to determine predictors of depression outcomes is limited.

\section{Course of depression}

History and duration

Limosin et al. [43] reported that the current episode of depression was not the first for 38\% of the patients in their study. In that study, the average number of previous depressive episodes was 2.1 (SD 1.7 episodes; range 1-12) and the average time reported between the first and current depressive episode was 5.9 years (SD 5.8 years; range 0.5 to 30 years).

Only four of the 17 studies provide information on the chronicity of depressive symptoms [37,43,58,65]. The mean duration of the current episode of depression varied across the two studies that reported it. Limosin et al. [43] reported the average length of the current episode of depression was 2.8 months (SD 7 months; range 0.5 to 8 years), while in the Groningen Primary Care Study, the mean episode duration for depressive disorders was 9 to 10 months [65], however the small sample size in the Groningen study and non-random selection of patients in both studies limits the generalisability of these findings. Ronalds et al. [37] reported a greater improvement in depressive disorder for patients with a depressive disorder of less than six months duration compared to patients with a duration of greater than six months. In the Groningen Primary Care Study, patients with depression, anxiety or neurasthenia disorders with a recent onset or exacerbation, were twice as likely to have that disorder recognized by a GP and to have improved at follow-up, than patients with chronic psychological disorders [64]. 


\section{Recovery}

Eight studies have presented data on recovery from major depressive disorder. Among these, 32\% of patients had recovered at four months [67], 65-71\% had recovered at six months $[43,61,66], 35 \%$ had recovered at nine months [52], 32\%-67\% had recovered at 12 months $[41,42,54,64,69,70]$ and $47 \%$ had recovered at 3.5 years [35] (Table 2). It is not possible to meaningfully compare the findings across studies as there was no consistency in methods, with studies using different instruments for screening and diagnosis, and different methods of recruitment and administration (clinician administered, researcher administered or self report) of instruments (Table 1). Furthermore, four of these studies included small numbers of patients with depression; Schulberg et al. [66] followed up 17 patients with major depressive disorder, Ormel et al. [35] followed up 20 patients with depression and 13 with borderline depression, Rost et al. [67] followed up 38 patients with major depressive disorder and Wagner et al. [54] followed up 51 patients with major depression and 66 with minor depression. There were three studies with large sample sizes that presented data on recovery from major depression/depressive disorder. In France, Limosin et al. [43] found that 65\% (308/ 476) of patients with major depressive disorder recovered without relapse at six months; at nine month follow-up, the LIDO study [52] conducted in six countries, found that 35\% (340/968) of patients reported complete remission from major depressive disorder (ranged from 25\%$48 \%$ across countries); and in the WHO Collaborative Project on Psychological Problems in General Health Care conducted in 14 countries, 67\% (482/725) of patients with depressive episodes recovered at 12 months [41]. Although both the LIDO and WHO studies administered (different versions of) the CIDI, the results of the studies are very different. The authors of the LIDO study offer no explanation for the lower rate of recovery in their study compared to other studies [52], however these follow-ups were done at nine and 12 months respectively which may contribute to the recovery rates.

The interpretation of the findings on recovery is further complicated when recovery rates are compared for patients whose depression was detected or undetected $[38,46,49,64,66]$. Despite the methodological limitations of some of the studies presented such as small sample size; the results suggest there is no difference in depression outcomes between patients whose depression is recognized or unrecognized. Rost et al. [38] reported that $47.2 \%$ of undetected patients and $39 \%$ of detected patients no longer met criteria for major depression at 12 month follow-up. At six month follow-up, Schulberg [66] found that "psychiatric status at initial assessment and the number of assigned medical diagnoses rather than the physician's recognition and treatment of depression strongly predict continued affective disorder" (p.312), however, only 6.2\% and $2.9 \%$ of this cohort had major depressive disorder at baseline and follow-up respectively. In the WHO Psychological Problems in General Health Care study conducted in 14 countries, Simon et al. [46] found that at baseline recognized patients had significantly higher mean GHQ scores and were more disabled than unrecognized patients. At three month follow-up, recognized patients reported a significantly greater reduction in GHQ scores than unrecognized patients; however by 12 month follow-up there was no difference between recognized and unrecognized patients in change in GHQ score or change in diagnostic status from baseline. The authors conclude that "recognition and appropriate diagnosis of depression in primary care is associated with significantly greater short-term improvement [and] that increasing recognition of depression in primary care is only a first step toward more appropriate treatment" (p.97). In the Groningen Primary Care Study at 12 month follow-up psychopathology had improved for $75 \%$ of patients whose psychological disorder was recognized $(\mathrm{n}=100)$ by a GP compared to $33 \%$ of unrecognized patients $(\mathrm{n}=79)(\mathrm{p}<0.001)$ (OR 6.1 for PSE-ID) [64]. A similar pattern was found with improvement in social disability: a significantly greater proportion of recognized patients compared to unrecognized patients reported improvement at 12 months (56\% vs. 24\%, p < $0.001)(\mathrm{OR}=4.0)$. The majority of participants in this study were 'new' cases (i.e. a psychiatric diagnosis had not been diagnosed during the 12 months prior to the index visit) which may explain in part why the results conflict with the results from the other studies presented.

\section{Relapse rates}

Only two studies in the current review presented data on relapse rates [32,43]. Limosin et al. [43] reported at six months that $65 \%(308 / 476)$ of patients with major depressive disorder had recovered without relapse, $25 \%$ (117/476) developed a chronic condition and 11\% (51/ 476) relapsed after recovery. In the Groningen Primary Care Study, 93\% of depressed patients had remitted from index episode at 12 months [32] and the relapse (described as "transition from an asymptomatic state of at least two months to a state of mental disorder") rate among depressed patients was 30\%, however the cohort included only 20 participants with major depression. Limosin et al. [43] found that a history of recurrent major depressive disorder was associated with a higher risk of relapse at six months, while Parker et al. [68] found patients with episodic or recurrent episodes were more likely to improve at 20 weeks than those with other patterns of depression, however due to this study's small sample size and short follow-up time (20 weeks) the results should be considered tentatively. 


\section{Risk factors for the course of major depressive disorder and depressive symptoms}

Six studies examined the predictors of the course of depression [32,41-43,52,58,67].

\section{Chronicity of depression}

Longer pre-baseline duration of the depressive episode in the WHO Collaborative Project on Psychological Problems in General Health Care study was a predictor of a poor course of depression [58]. Multivariate analysis reported that among those whose pre-baseline duration was at least one year compared to those whose pre-baseline duration was less than three months, the odds of a poor short-term course of depression (no full recovery within half a year) were over five times higher (versus those whose pre-baseline duration was less than three months) ( $\mathrm{OR}=5.22,95 \% \mathrm{CI} 2.45-11.15)$. The same was found for long-term outcomes, with those who had a prebaseline duration of one year being more likely to report a poor outcome compared to those whose pre-baseline duration was less than one year $(\mathrm{OR}=3.54,95 \%$ CI $1.67-$ 7.52). In the Groningen Primary Care study, duration of index episode was not associated with the occurrence of a relapse within the 12 month follow-up after remission [32].

\section{Severity of depression}

Wagner et al. [54] found that a greater proportion of patients with minor depression $(56 \%, 37 / 66)$ than major depression $(37 \%, 19 / 51)$ at baseline were asymptomatic at 12 months. They found that a diagnosis of minor depression was associated with almost the same degree of impairment in health status, functional status and disability, and psychiatric service utilization as a diagnosis of major depression. However, 20\% (13/66) of patients with minor depression at baseline met criteria for major depression at 12 months, while 22\% (11/51) of patients with major depression at baseline met criteria for minor depression at 12 months. The authors conclude that subthreshold depression or the persistence of depressive symptoms is a risk for developing major depression. In the Groningen Primary Care Study, 31\% of patients with borderline depression had recovered at 12 months and $70 \%$ at 3.5 years [35]. Indeed, the Groningen Primary Care Study [35] found that partial remission rather than complete recovery "was the rule and was associated with residual disability" (p.759). This study also found that depression had better outcomes than anxiety and mixed anxiety-depression. At baseline, patients with both anxiety and depression reported the highest symptoms levels on the Present State Exam. However given the small sample size with each disorder these results should be interpreted with caution.
The data from studies measuring depressive symptoms are also difficult to compare for similar reasons. Parker et al. [68] reported a 6\% improvement in depressive symptoms at 20 weeks; and others reported that depressive symptoms had significantly reduced at six month follow-up $[37,51]$. At four and a half month follow-up, one study found a significant reduction in depressive symptom scores among primary care patients whose depression was not detected compared to no significant reduction in depressive symptom scores among detected patients [49]. Kessler et al [45] reported that of the 88 patients who met criteria for a case on the GHQ, 50\% (16/32) of those not detected by a GP at baseline or during the three year follow up, were no longer cases at three year follow-up. Grembowski et al. [51] and Ronalds et al. [37] retained a large sample of patients at follow-up, however Grembowski et al. [51] only included insured patients and therefore their findings are limited to a sample of mainly middle-class, Caucasian adults with depressive symptoms. The other three studies followed up small numbers of patients and may not have had sufficient power to determine reduction in depressive symptoms $[45,49,68]$.

There were two studies where improvement in depressive symptoms was presented $[37,68]$. Parker et al. [68] found that baseline predictors of a "better outcome" for the 20 patients with depressive symptoms at baseline who were followed up for 20 weeks were: having a history of episodic or recurrent episodes; a more severe depression; lower social class; break up of an intimate relationship as a precipitant; a neutralizing life event and family support. Multivariate analysis conducted by Ronalds et al. [37] found that at six month follow-up, high baseline depression score, higher educational level and current employment were associated with greater reduction in depression score among patients with major depressive disorder and generalized anxiety or panic disorders at baseline. The factors associated with outcome in this study were not reported for patients with each disorder, therefore it is difficult to draw any firm conclusions about the factors associated with improvement in depression among depressed patients.

\section{Comorbidity}

Gaynes et al. [42] reported that the risk for persistent depression at 12 months for those with major depression at baseline was $44 \%$ greater in those with co-existing anxiety disorder $(\mathrm{RR}=1.44,95 \% \mathrm{CI} 1.02-2.04)$. In the Groningen Primary Care Study, half of the patients who experienced a positive life change remitted within four months [32], the probability of remission was 2.3 times higher following positive life change $(\mathrm{HR}=2.3)$. The positive life change increased the probability of remission in women fourfold but not in men $(\mathrm{HR}=4.4)$. Multivariate analysis found that quicker time to remission was associ- 
ated with low severity of pre-morbid difficulties (HR = $0.7)$, high self-esteem $(\mathrm{HR}=1.4)$, and a coping style aimed at reducing tension $(\mathrm{HR}=1.4)$.

\section{Treatment}

Rost et al. [67] reported that patients with major depression who received pharmacologic treatment concordant with guidelines between baseline and five month followup were more likely to be in remission at follow-up than subjects who did not, however the sample size was small and of the 38 patients followed up, only 11 received such treatment. The findings on whether being prescribed antidepressants was associated with recovery were conflicting. Rost et al. [67] reported that patients who received pharmacologic treatment concordant with guidelines between index visit and five month follow-up were more likely to be in remission at follow-up than subjects who did not, while Barkow et al. [41] found antidepressant use was related to persisting depression at 12 month follow-up. The WHO Mental Disorders in General Health Care Study found that while patients receiving antidepressants reported significantly less symptoms on the GHQ at three months than patients receiving sedatives, this was not the case at 12 months [56]. However the authors highlight that as the study was not a trial, efficacy of psychoactive drugs cannot be inferred.

\section{Sex}

Despite the majority of patients in the 17 studies being female, only three studies reported on outcome by sex $[37,41,68]$. All three studies reported no difference between depression outcome for males and females at follow-up. However two of these studies may not have had sufficient power to detect differences between males and females $[37,68]$.

\section{Predictors of the course of depression from multivariate analyses} Whilst there are difficulties in comparing results across the three large scale studies that measured risk factors for persistence or recovery from depression $[41,43,52,58]$, some conclusions can be drawn. Remission from depression at nine months was associated with higher level of education $(\mathrm{OR}=1.06,95 \%$ CI 1.051-1.11), higher quality of life ( $\mathrm{OR}=0.94,95 \%$ CI 0.92-0.97) and experiencing key life events $(\mathrm{OR}=0.71,95 \% \mathrm{CI} 0.66-0.83)$ in the LIDO study, after adjusting for centres, socio-demographic data, severity of depression, co-morbidity and general quality of life [52]. A significantly greater proportion of patients whose major depression had remitted at nine month follow-up had medical conditions, dysthymia or anxiety disorders than patients who were not in complete remission. While the authors found that there was no consistent variable that predicted remission across the six country sites, they believed this may have been a result of the "modest" sample size (range in cohort sizes by country 142-185).
In the WHO Collaborative Project on Psychological Problems in General Health Care study, sustained non-remission (i.e. presence of a non-remitted or new depression) at 12 month follow-up was associated with lower levels of education $(0$ years versus $11+$ years: $\mathrm{OR}=3.78,95 \% \mathrm{CI}$ $1.83-7.79 ; 1-5$ years versus $11+$ years $\mathrm{OR}=1.81,95 \% \mathrm{CI}$ 1.02-3.19), unemployment (employed versus unemployed: OR $=1.57,95 \%$ CI 1.02-2.43), severity of depression (severe versus moderate: $\mathrm{OR}=3.27,95 \% \mathrm{CI} 1.91$ 5.62), antidepressant use ( $\mathrm{OR}=1.79,95 \%$ CI 1.06-3.03), repeated suicidal thoughts ("crossed my mind" versus no suicidal thoughts) $(\mathrm{OR}=1.82,95 \%$ CI $1.14-2.93)$, and abdominal pain as main reason for consulting the general practitioner $(\mathrm{OR}=2.30,95 \% \mathrm{CI} 1.17-4.52)$ [41]. The study also reported that patients had a greater probability of a poor long term course (no recovery over the 12 month follow-up period) if the severity of their depression was moderate or worse (versus mild) $(\mathrm{OR}=3.38$, $95 \%$ CI 1.49-7.65), their pre-baseline duration was greater than one year (versus less than one year) $(\mathrm{OR}=$ $3.54,95 \%$ CI $1.67-7.52)$, they did not have a chronic physical illness (OR $=0.31,95 \%$ CI $0.13-0.73)$, they had low social support (versus high/average) ( $\mathrm{OR}=0.45,95 \%$ CI 0.19-1.07), and they had lower levels of education ( $\geq$ 13 years versus $<10$ years $)(\mathrm{OR}=0.18,95 \% \mathrm{CI} 0.07-0.47)$ [58]. A previous episode of depression increased the probability of chronicity for younger $(\mathrm{OR}=3.60,95 \% \mathrm{CI}$ $0.92-14.14$ ) but not older (OR $=0.28,95 \%$ CI $0.05-1.45$ ) patients. They found that among patients with co-morbid anxiety, depressed women had a smaller probability of chronicity than depressed men (OR $=0.13,95 \%$ CI $0.04-$ 0.41) [58]. Limosin et al reported that relapse from depression was associated with a history of recurrent major depressive disorder at six month follow-up ( $\mathrm{OR}=$ $1.6,95 \%$ CI $1.08-3.43$ ) [43].

Risk factors for persistence of depression identified in this review were: severity and chronicity of the depressive episode, the presence of suicidal thoughts, antidepressant use, poorer self-reported quality of life, lower selfreported social support, experiencing key life events, lower education level and unemployment.

\section{Treatment and health service use}

The proportion of patients receiving antidepressant medication during the study follow-up period ranged from $0 \%$ (St Petersbourg site in Fleck et al. [52]) to 100\% [43] (Table 2). However, the proportion of these patients prescribed antidepressants according to guidelines in the three studies that reported this, ranged from $27 \%$ [38] to $61 \%[41]$.

Three studies reported that the likelihood of receiving treatment was associated with severity of illness $[51,54,71]$. In addition, The WHO Mental Disorders in 
General Health Care Study found that younger age, being male and less time since first onset were associated with not being prescribed psychoactive drugs [56]. Grembowski et al. [51] found that more severe depressive symptoms at baseline, previously attending a mental health specialist, more years of education, younger age and being female were the best predictors of referral and utilization of a mental health specialist and that managed care was not associated with a reduced likelihood of referral to or of visiting a mental health specialist. Another study found major depression (OR 1.83), female gender (OR 2.17), white race (OR 2.34), and higher education (OR 1.21) were associated with higher odds of a mental health visit in the last four months [54]. The US site of the WHO Collaborative Project on Psychological Problems in General Health Care found that participants with higher symptom severity as measured by the GHQ-28 at baseline, and more disability, were more likely to receive antidepressant medication or use any specialty mental health services [71]. This study also reported that patients with anxiety or depressive disorders at baseline had higher health care costs in the six months prior to baseline (US $\$ 2,390$ ) than patients with sub-threshold (US \$1,098) or no disorders (US $\$ 1,397$ ). These cost differences were due to higher use of general medical services rather than higher mental health treatment costs [57]. In the Groningen Primary Care Study, recognition of psychiatric disorder by a GP among new cases resulted in greater likelihood of referral to a mental health specialist (OR 3.0), receiving psychotropic medications (OR 4.5), having a counseling session (OR 12.2) and having any mental health treatment (OR 6.7) [64].

\section{Discussion}

Understanding the complex interplay between the development and persistence of depression over the longer term, psychological, social and physical factors and the health service use and treatment patterns is crucial if we are to plan better models of care to cope with the increasing burden that depression and related disorders is placing on people experiencing the condition, their social networks and the health care system.

Despite the growing interest in depression being managed as a chronic illness in primary care; this review identified only 17 observational studies of depression in primary care, most of which have been conducted in Europe or the US. The striking finding of this review is the small sample size of many studies, the small numbers in the cohort with depression and the short length of follow-up. The studies provide information on the nature and course of depression for around 7,500 people receiving routine primary care. Of the 17 studies, nine studies followed almost 3,000 patients from four countries for less than 12 months, six followed almost 4,000 patients from 19 coun- tries for 12 months, and two followed over 500 patients from two countries for longer than 12 months. Only five studies included large sample sizes (greater than 400 patients) $[43,44,51,63,69]$ and only three of them reported risk factors for the course of depression $[41,43,52,58]$.

The review aimed to identify risk factors for persistence of depression that were common across studies. This was difficult as the factors studied and measurement tools used varied widely. Few studies included psychiatric, physical and social risk factors together, thus preventing us from reporting on the relative importance of each of these. Based on this review, of the factors studied, it appears that the severity and chronicity of the depressive episode, the presence of suicidal thoughts, antidepressant use, comorbid physical illness, poorer self-reported quality of life, lower self-reported social support, negative life events, lower education level and unemployment are all factors associated with the persistence of depression.

Several gaps in the studies included in this review have been identified. In particular there is inconsistency in the way depression is defined (symptoms or disorders), how it is measured and the risk factors that are studied. Nonpsychiatric co-morbidities, social and contextual factors have been poorly explored. Health service use and treatment is not well documented and studies lack patients' qualitative experience of depression.

The 17 studies can be grouped into two major types; those that focus on the nature and course of depressive symptoms and those that focus on the nature and course of major depressive disorder. Recent research by Simon et al. [19] suggests that the more prevalent conditions, such as minor depression and dysthymia, place a greater burden on the health care system than the less prevalent major depression; yet, many studies reviewed focused on individuals experiencing major depression. The debate regarding use of diagnostic categories versus symptom severity in research and clinical practice is ongoing [75,76] and studies that include the capacity to measure both will add valuable information to assist researchers and clinicians as we develop future classificatory systems and clinical guidelines. We urgently need better consistency in the terminology used in reported research as even among studies including patients with major depression in the cohort, the terminology used varied across cohorts (Table 1).

The review found that for some, depression is a chronic and relapsing disorder, with studies reporting recovery from a major depressive disorder at 12 months for between one to two thirds of patients. The variation in recovery across studies may be due in part to the different methods used in each study, or because people recruited 
into each cohort differ. As none of the studies recruited a random sample of patients, the generalisability of findings is problematic.

The studies reviewed highlight the complex and changing nature of depression as it exists in a primary care sample; symptoms improve and deteriorate over time (how this relates to treatments received is difficult to judge) and patients can oscillate between depression categories.

We are unable to reliably report on relapse rates asonly two studies report relevant data stating rates of $11 \%$ at six monthsand $30 \%$ at 12 months. Establishing reliable estimates ofdepression relapse in the primary care setting requires follow-up of larger samplesover a longer time frame.

It is widely reported that women experience depression about twice as much as men [77], despite this none of the studies reviewed reported on risk factors for persistence of depression for males and females separately. Given the higher prevalence of depression among females, studies should analyse the results by sex whenever the sample size allows.

Current guidelines for management of depression in primary care are constructed for use, in the main, with newly diagnosed cases of depression that are not complicated by physical comorbidities and social factors. This review demonstrates that newly diagnosed cases of depression are relatively uncommon, that physical comorbidities are common and that social factors, when studied are associated with poorer outcomes. Future guidelines should take into account the findings of the naturalistic studies and not rely solely upon evidence gathered in randomized controlled treatment trials.

\section{Conclusion}

Naturalistic studies that document the personal experience, treatment and service use and take account of the psychological, physical and social factors influencing depression outcomes are essential for future service planning. We hope this review will assist others to plan their studies and enable them to address the methodological limitations of previous research.

\section{Competing interests}

The author(s) declare that they have no competing interests.

\section{Authors' contributions}

GG and JG agreed the search terms for the review, GG searched the electronic databases and articles were assessed as relevant by both authors. GG and JG drafted the manuscript. Both authors read and approved the final manuscript.

\section{Acknowledgements}

Gail Gilchrist's position is funded by a National Health and Medical Research Council Project Grant [grant id. 299869]. The National Health and Medical Research Council had no role in study design; in the collection, analysis, and interpretation of data; in the writing of the manuscript; and in the decision to submit the manuscript for publication. Jane Gunn's position is funded by The University of Melbourne. We would like to thank Tania Celeste and Patrick Condron, Information Consultants, The University of Melbourne for their assistance with the literature review.

\section{References}

I. Murray C, Lopez A: The Global Burden of Disease. Boston, Mass, World Health Organisation and Harvard University Press; 1996.

2. Culpepper $L$ : The active management of depression. Journal of Family Practice 2002, 5 I:769-776.

3. Lin EH, Katon WJ, VonKorff M, Russo JE, Simon GE, Bush TM, Rutter CM, Walker EA, Ludman E: Relapse of depression in primary care. Rate and clinical predictors. Archives of Family Medicine 1998, 7:443-449.

4. Katon W, Schulberg H: Epidemiology of Depression in Primary Care. General Hospital Psychiatry 1992, I 4:237-247.

5. van Weel-Baumgarten EM, Schers HJ, van den Bosch WJ, van den Hoogen H, Zitman FG: Long-term follow-up of depression among patients in the community and in family practice settings: A systematic review. The Journal of Family Practice 2000, 49: I I |3-I I 20.

6. Gunn J: Depression as a chronic and disabling experience. The DIAMOND study: a longitudinal naturalistic study of depression in primary care in Victoria, Australia. Journal of Affective Disorders 2006, 91 :S2I.

7. Blacker CV, Clare AW: Depressive disorder in primary care. British Journal of Psychiatry 1987, I 50:737-75I.

8. Tylee A: Major Depressive Disorder (MDD) from the patient's perspective: overcoming barriers to appropriate care. International Journal of Psychiatry in Clinical Practice 2001, 5:s37-s42.

9. van Schaik DJF, Klijn AFJ, van Hout HPJ, van Mrwijk HWJ, Beekman ATF, de Haan M, van Dyck R: Patients' preferences in the treatment of depressive disorder in primary care. General Hospital Psychiatry 2004, 26:184-189.

10. Cuijpers P, Smit F, Willemse G: Predicting the onset of major depression in subjects with subthreshold depression in primary care: a prospective study. Acta Psychiatrica Scandinavica 2005, I I I: I33-138.

II. Dowrick C: Does testing for depression influence diagnosis or management by general practitioners? Family Practice 1995, I 2:46|-465.

12. Patience DA, McGuire RJ, Scott AI, Freeman CP: The Edinburgh Primary Care Depression Study: personality disorder and outcome. British Journal of Psychiatry 1995, 167:324-330.

13. Ostler K, Thompson C, Kinmonth ALK, Peveler RC, Stevens L, Stevens A: Influence of socio-economic deprivation on the prevalence and outcome of depression in primary care: the Hampshire Depression Project. British Journal of Psychiatry 200I, I 78: 12-17.

14. Smith JL, Rost KM, Nutting PA, Elliott C E., Dickinson ML: Impact of ongoing primary care intervention on long term outcomes in uninsured and insured patients with depression. Medical Care 2002, 40:1210-1222.

15. Wells K, Sherbourne C, Duan N, Unutzer J, Miranda J, Schoenbaum M, Ettner SL, Meredith LS, Rubenstein L: Quality improvement for depression in primary care: Do patients with subthreshold depression benefit in the long run? American Journal of Psychiatry 2005, I 62: I|49-I I57.

16. Zung WWK, Magruder-Habib K, Velez R, Alling W: The comorbidity of anxiety and depression in general medical patients: $A$ longitudinal study. Journal of Clinical Psychiatry 1990, 5 I:77-80.

17. Rollman BL, Hanusa BH, Belnap BH, Gardner W, Cooper LA, Schulberg HC: Race, quality of depression care, and recovery from 
major depression in a primary care setting. General Hospital Psychiatry 2002, 24:38I-390.

18. Simon GE, Revicki D, Heiligenstein J, Grothaus L, VonKorff M, Katon WJ, Hylan TR: Recovery from depression, work productivity, and health care costs among primary care patients. General Hospital Psychiatry 2000, 22:153-162.

19. Simon GE: Long-term prognosis of depression in primary care. Bulletin of the World Health Organization 2000, 78:439-445.

20. Van Os TWDP, Van den Brink RHS, Van Der Meer K, Ormel J: The care provided by general practitioners for persistent depression. European Psychiatry 2006, 21 :87-92.

21. Valenstein M, Ritsema T, Green LA, Blow FC, Mitchinson A, McCarthy JF, Barry KL, Hill E: Targeting quality improvement activities for depression: Implications of using administrative data. Journal of Family Practice 2000, 49:72I-728.

22. van Weel-Baumgarten EM, van den Bosch WJ, van den Hoogen $H J$, Zitman FG: Ten year follow-up of depression after diagnosis in general practice. British Journal of General Practice 1998, 48:1643-1646.

23. Van Weel-Baumgarten EM, Van den Bosch WJ, Van den Hoogen HJ, Zitman FG: The long-term perspective: A study of psychopathology and health status of patients with a history of depression more than 15 years after the first episode. General Hospital Psychiatry 2000, 22:399-404.

24. Wilson I, Duszynski K, Mant A: A 5-year follow-up of general practice patients experiencing depression. Family Practice 2003, 20:685-689.

25. Luber MP, Hollenberg JP, Williams-Russo P, DiDomenico TN, Meyers BS, Alexopoulos GS, Charlson ME: Diagnosis, treatment, comorbidity, and resource utilization of depressed patients in a general medical practice. International Journal of Psychiatry in Medicine 2000, 30: $1-13$.

26. Van Weel-Baumgarten EM, Van den Bosch WJ, Hekster YA, Van den Hoogen HJ, Zitman FG: Treatment of depression related to recurrence: 10-Year follow-up in general practice. Journal of Clinical Pharmacy \& Therapeutics 2000, 25:6I-66.

27. Vuorilehto M, Melartin T, Isometsa ET: Depressive disorders in primary care: Recurrent, chronic, and co-morbid. Psychological Medicine 2005, 35:673-682.

28. Simon GE, Von Korff M, Lin E: Clinical and functional outcomes of depression treatment in patients with and without chronic medical illness. Psychological Medicine 2005, 35:27I-279.

29. Joo JH, Solano FX, Mulsant BH, Reynolds CF, Lenze EJ: Predictors of Adequacy of Depression Management in the Primary Care Setting. Psychiatric Services 2005, 56:1524-1528.

30. Saraceno B, Laviola F, Sternai E, Terzian E, Tognoni G: Consequences of mental distress recognition in general practice in Italy : a follow-up study. Social Science \& Medicine 1994 39:789-796.

31. Vazquez-Barquero JL, Garcia J, Simon JA, Iglesias C, Montejo J, Herran A, Dunn G: Mental health in primary care. An epidemiological study of morbidity and use of health resources. $\mathrm{Br} J$ Psychiatry 1997, I 70:529-535.

32. Oldehinkel AJ, Ormel J, Neeleman J: Predictors of time to remission from depression in primary care patients: Do some people benefit more from positive life change than others? Journal of Abnormal Psychology 2000, 109:299-307.

33. Ormel J, Von Korff M, Van den Brink W, Katon W, Brilman E, Oldehinkel T: Depression, anxiety, and social disability show synchrony of change in primary care patients. American Journal of Public Health 1993, 83:385-390.

34. Ormel J, Vonkorff M, Oldehinkel AJ, Simon G, Tiemens BG, Ustun TB: Onset of disability in depressed and non-depressed primary care patients. Psychological Medicine 1999, 29:847-853.

35. Ormel J, Oldehinkel T, Brilman E, van den Brink W: Outcome of depression and anxiety in primary care. A three-wave 3 I/2year study of psychopathology and disability. Archives of General Psychiatry 1993, 50:759-766.

36. Pini S, Perkonnig A, Tansella M, Wittchen HU, Psich D: Prevalence and I2-month outcome of threshold and subthreshold mental disorders in primary care. Journal of Affective Disorders 1999, 56:37-48.

37. Ronalds C, Creed F, Stone K, Webb S, Tomenson B: Outcome of anxiety and depressive disorders in primary care. British Journal of Psychiatry 1997, I 71:427-433.
38. Rost K, Zhang M, Fortney J, Smith J, Coyne J, Smith GRI: Persistently poor outcomes of undetected major depression in primary care. General Hospital Psychiatry 1998, 20:12-20.

39. Simon GE, Fleck M, Lucas R, Bushnell DM: Prevalence and predictors of depression treatment in an international primary care study. American Journal of Psychiatry 2004, 16 I:1626-1634.

40. Simon GE, Chisholm D, Treglia M, Bushnell D: Course of depression, health services costs, and work productivity in an international primary care study. General Hospital Psychiatry 2002, 24:328-335.

4I. Barkow K, Maier W, Ustun TB, Gansicke M, Wittchen HU, Heun R: Risk factors for depression at 12-month follow-up in adult primary health care patients with major depression: an international prospective study. Journal of Affective Disorders 2003, 76:157-169.

42. Gaynes BN, Magruder KM, Burns BJ, Wagner HR, Yarnall KS, Broadhead WE: Does a coexisting anxiety disorder predict persistence of depressive illness in primary care patients with major depression? General Hospital Psychiatry 1999, 21:158-167.

43. Limosin F, Loze JY, Zylberman-Bouhassira M, Schmidt ME, Perrin E, Rouillon F: The course of depressive illness in general practice. Canadian Journal of Psychiatry - Revue Canadienne de Psychiatrie 2004, 49: I19-123

44. Herrman H, Patrick DL, Diehr P, Martin ML, Fleck M, Simon GE, Buesching DP: Longitudinal investigation of depression outcomes in primary care in six countries: the LIDO study. Functional status, health service use and treatment of people with depressive symptoms. Psychological Medicine 2002, 32:889-902.

45. Kessler D, Bennewith O, Lewis G, Sharp D: Detection of depression and anxiety in primary care: follow up study. British Medical Journal 2002, 325:1016-1017.

46. Simon GE, Goldberg D, Tiemens BG, Ustun TB: Outcomes of recognized and unrecognized depression in an international primary care study. General Hospital Psychiatry 1999, 21:97-105.

47. Klinkman MS, Schwenk TL, Coyne JC: Depression in primary care--more like asthma than appendicitis: the Michigan Depression Project. Canadian Journal of Psychiatry Revue Canadienne de Psychiatrie 1997, 42:966-973.

48. Manning JS, Haykal RF, Connor PD, Akiskal HS: On the nature of depressive and anxious states in a family practice setting: the high prevalence of bipolar II and related disorders in a cohort followed Iongitudinally. Comprehensive Psychiatry 1997, 38: $102-108$

49. Coyne JC, Klinkman MS, Gallo SM, Schwenk TL: Short-term outcomes of detected and undetected depressed primary care patients and depressed psychiatric patients. General Hospital Psychiatry 1997, 19:333-343.

50. Leenstra AS, Ormel J, Giel R: Positive life change and recovery from depression and anxiety. A three-stage longitudinal study of primary care attenders. British Journal of Psychiatry 1995, 166:333-343.

5I. Grembowski DE, Martin D, Patrick DL, Diehr P, Katon W, Williams B, Engelberg R, Novak L, Dickstein D, Deyo R, Goldberg H: Managed care, access to mental health specialists, and outcomes among primary care patients with depressive symptoms. Journal of General Internal Medicine 2002, 17:258-269.

52. Fleck M, Simon G, Herrman H, Bushnell D, Martin M, Partrick D: Major depression and its correlates in primary care settings in six countries. 9-month follow-up study. British Journal of Psychiatry 2005, 186:4I-47.

53. van den Brink W, Leenstra A, Ormel J, van den Willige G: Mental health intervention programs in primary care: their scientific basis. Journal of Affective Disorders 1991, 21:273-284.

54. Wagner HR, Burns B], Broadhead WE, Yarnall KS, Sigmon A, Gaynes $\mathrm{BN}$ : Minor depression in family practice: functional morbidity, co-morbidity, service utilization and outcomes. Psychological Medicine 2000, 30:1377-1390.

55. Tiemens BG, Ormel J, Simon GE: Occurrence, recognition, and outcome of psychological disorders in primary care. American Journal of Psychiatry 1996, I 53:636-644.

56. Goldberg D, Privett M, Ustun B, Simon G, Linden M: The effects of detection and treatment on the outcome of major depression in primary care: a naturalistic study in 15 cities. British Journal of General Practice 1998, 48: 1840-1844. 
57. Simon G, Ormel J, VonKorff M, Barlow W: Health care costs associated with depressive and anxiety disorders in primary care. American Journal of Psychiatry 1995, I 52:352-357.

58. van den Brink RH, Ormel J, Tiemens BG, Smit A, Jenner JA, van der Meer K, van Os TW: Predictability of the one-year course of depression and generalized anxiety in primary care. General Hospital Psychiatry 2002, 24:156-163.

59. Blacker CV, Thomas JM, Thompson C: Seasonality prevalence and incidence of depressive disorder in a general practice sample: identifying differences in timing by caseness. Journal of Affective Disorders 1997, 43:4I-52.

60. Kessler D, Lloyd K, Lewis G, Gray DP: Cross sectional study of symptom attribution and recognition of depression and anxiety in primary care. British Medical Journal 1999:436-440.

6I. Kessler LG, Cleary PD, Burke JD Jr.: Psychiatric disorders in primary care. Results of a follow-up study. Archives of General Psychiatry 1985, 42:583-587.

62. Chisholm D, Amir M, Fleck M, Herrman H, Lomachenkov A, Lucas R, Patrick D: Longitudinal Investigation of Depression Outcomes (the Lido study) in primary care in six countries: Comparative assessment of local health systems and resource utilization. International Journal of Methods in Psychiatric Research 200I, 10:59-7I.

63. MaGPle Research Group: The nature and prevalence of psychological problems in New Zealand primary healthcare: a report on Mental Health and General Practice Investigation (MaGPle). New Zealand Medical Journal 2003, I l6:U379.

64. Ormel J, Van Den Brink W, Koeter MW, Giel R, Van Der Meer K, Van De Willige G, Wilmink FW: Recognition, management and outcome of psychological disorders in primary care: a naturalistic follow-up study. Psychological Medicine 1990, 20:909-923.

65. Ormel J, Koeter MWJ, Van den Brink W, Van de Willige G: Recognition, management, and course of anxiety and depression in general practice. Archives of General Psychiatry 1991, 48:700-706.

66. Schulberg HC, McClelland M, Gooding W: Six-month outcomes for medical patients with major depressive disorders. Journal of General Internal Medicine 1987, 2:3 I2-3 I7.

67. Rost K, Williams C, Wherry J, Smith GRJ: The process and outcomes of care for major depression in rural family practice settings. Journal of Rural Health 1995, I I: I |4-121.

68. Parker G, Holmes S, Manicavasagar V: Depression in general practice attenders. "Caseness", natural history and predictors of outcome. Journal of Affective Disorders 1986, 10:27-35.

69. Sartorius N, Ustun TB, Costa e Silva JA, Goldberg D, Lecrubier Y, Ormel J, Von Korff M, Wittchen HU: An international study of psychological problems in primary care. Preliminary report from the World Health Organization Collaborative Project on 'Psychological Problems in General Health Care'. Archives of General Psychiatry 1993, 50:819-824.

70. Ustun TB: WHO collaborative study: An epidemiological survey of psychological problems in general health care in 15 centers worldwide. International Review of Psychiatry 1994, 6:357-363.

7I. Simon GE, VonKorff M: Recognition, management, and outcomes of depression in primary care. Archives of Family Medicine 1995, 4:99-105.

72. Radloff LS: The CES-D scale: a self report major depressive disorder scale for research in the general population. Applied Psychological Measurement 1977, I:305-40I.

73. Goldberg DP, Hillier VF: A scaled version of the General Health Questionnaire,. Psychological Medicine 1979, 9:।39-I45.

74. Pirotta M, Gunn J, Harrison D: Accurate sampling in general practice waiting room surveys: methodological issues. Australian \& New Zealand Journal of Public Health 2002, 26: I52-155.

75. Helzer JE, Kraemer HC, Krueger RF: The feasibility and need for dimensional psychiatric diagnoses. Psychological Medicine 2006, 36:167|-1680.

76. Kessler RC: The Categorical versus Dimensional Assessment Controversy in the Sociology of Mental Illness. Journal of Health and Social Behavior 2002, 43: I7|-I88.

77. Astbury J, Cabral M: Women's Mental Health: An Evidence Based Review. Geneva, World Health Organisation; 2000.

\section{Pre-publication history}

The pre-publication history for this paper can be accessed here:

http://www.biomedcentral.com/1471-2296/8/28/prepub
Publish with Biomed Central and every scientist can read your work free of charge

"BioMed Central will be the most significant development for disseminating the results of biomedical research in our lifetime. "

Sir Paul Nurse, Cancer Research UK

Your research papers will be:

- available free of charge to the entire biomedical community

- peer reviewed and published immediately upon acceptance

- cited in PubMed and archived on PubMed Central

- yours - you keep the copyright
BioMedcentral 